\title{
GAMBARAN KESEHATAN IBU DAN ANAK DENGAN PENDEKATAN KELUARGA DI RW 12 KALURAHAN MOJOSONGO SURAKARTA
}

\author{
The Description Of The Maternal And The Child Health With A Family Approach \\ In Rw 12 Mojosongo Surakarta \\ Ani Nur Fauziah ${ }^{1}$ Siti Maesaroh ${ }^{2}$ \\ STIKES Mamba'ul Ulum Surakarta \\ aninurfauziah@stikesmus.ac.id
}

\begin{abstract}
ABSTRAK
Latar Belakang Program Indonesia Sehat dengan Pendekatan Keluarga merupakan salah satu upaya yang dilakukan Puskesmas untuk meningkatkan jangkauan sasaran dan meningkatkan akses masyarakat pada pelayanan keluarga.

Tujuan Penelitian mendapatkan gambaran kondisi kesehatan ibu dan anak pada keluarga yang tinggal di RW 12 Kalurahan Mojosongo Surakarta yang meliputi : kondisi kesehatan ibu hamil serta kondisi kesehatan bayi dan balita..

Metode Penelitian penelitian deskriptif dengan pendekatan cross sectional. Populasi dalam penelitian ini adalah semua keluarga yang tinggal di RW 12 Kalurahan Mojosongo Surakarta , sedangkan tehnik pengambilan sampel menggunakan purposive sampling yaitu keluarga yang memiliki bayi,balita maupun ibu hamil dan mendapatkan rekomendasi dari kader sejumlah 204 keluarga. Alat pengumpulan data yang digunakan adalah kuesioner, sedangkan analisa data menggunakan distribusi frekuensi.

Hasil Penelitian Data Kesehatan bayi dan balita dari 178 bayi balita terdapat 4 bayi balita (2\%) yang tidak memiliki KMS ( Kartu Menuju Sehat), 8 bayi balita (4\%) yang tidak melakukan penimbangan rutin diposyandu, Terdapat 2 anak dengan status gizi sangat kurus $(1,1 \%), 9$ anak kurus $(5,1 \%)$ dan 7 anak gemuk $(3,9 \%)$ Data Kesehatan Ibu hamil dari 20 ibu hamil ada 2 ibu hamil $(10 \%)$ anemia ,ada 3 ibu hamil ( 15\%) mengalami Kurang Energi Kronis ( KEK), 3 ibu hamil ( $15 \%$ ) yang memiliki resiko serta ada 1 ibu hamil (5\%) yang menderita Hepatitis B. Selain itu ada 3 ibu hamil (15\%) yang tidak memiliki Buku Kesehatan Ibu dan Anak ( KIA), ada 5 ibu hamil (25\%) yang rumahnya belum terpasang stiker P4K ( Perencanaan Persalinan dan Pencegahan Komplikasi, 6 ibu hamil (30\%) yang tidak melakukan imunisasi Tetanus Toksoid TT) dan 5 ibu hamil (25\%) yang tidak mengkonsumsi tablet Fe

Simpulan data kesehatan ibu dan anak di RW 12 kalurahan Mojosongo surakarta untuk data kesehatan bayi balita adalah ada 8 bayi balita (4\%) yang tidak melakukan penimbangan rutin di posyandu, sedangkan untuk kesehatan ibu hamil ada 6 ibu hamil (30\%) yang tidak melakukan imunisasi tetanus toksoid.
\end{abstract}

Kata Kunci : Kesehatan, Ibu dan Anak, Pendekatan Keluarga

Gambaran Kesehatan Ibu Dan Anak Dengan Pendekatan Keluarga Di Rw 12 Kalurahan Mojosongo Surakarta (Ani Nur Fauziah, Siti Maesaroh) 


\begin{abstract}
Background : of the Healthy Indonesia Program with a Family Approach is one of the efforts made by the Puskesmas to increase the reach of the target and increase public access to family services.

Objective : The research objective was to get a picture of maternal and child health conditions in families living in $R W 12$ Kaljosongo Surakarta, which included: health conditions of pregnant women and health conditions of infants and toddlers .

Method: Research method is descriptive research with cross sectional approach. The population in this study were all families living in $R W 12$ Mojosongo Surakarta, while the sampling technique used purposive sampling, namely families that have babies, toddlers and pregnant women and get a cadre of 204 families. The data collection tool used is a questionnaire, while data analysis uses frequency distribution.

Result : Research Results Data on infants and toddlers' health from 178 toddlers has 4 infants (2\%) who do not have KMS (Card Towards Health), 8 infants (4\%) who do not carry out routine weighing diposyandu, 2 children with very nutritional status thin (1.1\%), 9 thin children (5.1\%) and 7 fat children (3.9\%) Health data Pregnant women from 20 pregnant women there were 2 pregnant women (10\%) anemia, there were 3 pregnant women (15\%) suffer from Chronic Energy Deficiency (KEK), 3 pregnant women (15\%) who have risk and there are 1 pregnant woman (5\%) who suffer from Hepatitis B. In addition there are 3 pregnant women (15\%) who do not have a Health Book Mother and Child (KIA), there are 5 pregnant women (25\%) whose houses have not yet installed P4K stickers (Maternity Planning and Complication Prevention, 6 pregnant women (30\%) who do not do Tetanus Toksoid TT immunization) and 5 pregnant women $(25 \%)$ who do not consume Fe tablets

Conclusion : The conclusions of maternal and child health data in $R W 12$ of Mojosongo Surakarta village for infant health data for infants are 8 toddlers (4\%) who do not carry out routine weighing in posyandu, while for pregnant women there are 6 pregnant women (30\%) who do not tetanus toxoid immunization.
\end{abstract}

Keywords: Health, Mother and Child, Family Approach

\title{
PENDAHULUAN
}

Kesehatan merupakan investasi untuk mendukung pembangunan ekonomi serta memiliki peran penting dalam upaya penanggulangan kemiskinan. Pembangunan kesehatan pada hakekatnya adalah upaya yang dilaksanakan oleh semua komponen Bangsa Indonesia yang bertujuan untuk meningkatkan kesadaran, kemamuan dan kemampuan hidup sehat bagi setiap orang agar terwujud derajad kesehatan masyarakat setinggi - tingginya.

Upaya pencapaian prioritas pembangunan kesehatan tahun 2015 - 2019

dalam Program Pembangunan Indonesia Sehat dilaksanakan dengan

Gambaran Kesehatan Ibu Dan Anak Dengan Pendekatan Keluarga Di Rw 12 Kalurahan Mojosongo Surakarta (Ani Nur Fauziah, Siti Maesaroh) 
mendayagunakan segenap potensi yang ada baik pemerintah pusat, provinsi, kabupaten /kota maupun masyarakat. Pembangunan kesehatan dimulai dari unit terkecil dari masyarakat yaitu keluarga.(Kemenkes RI, 2017)

Program Indonesia sehat merupakan salah satu program Nawa Cita ke 5 yaitu meningkatkan kualitas hidup manusia Indonesia. Program Indonesia Sehat dengan menegakkan 3 pilar utama yaitu : (1) Penerapan paradigma sehat, (2) Menguatkan pelayanan kesehatan dan (3) Pelaksanaan Jaminan Kesehatan Nasional (JKN). Pemerintah pusat dan pemerintah daerah. Pemerintah pusat dan pemerintah daerah menetapkan kebijakan pembangunan keluarga melalui pembinaan ketahanan dan kesejahteraan keluarga, untuk mendukung keluarga agar dapat melaksanakan fungsinya secara optimal. Sebagai penjabaran dari amanat Undang-Undang tersebut tersebut,Kementerian Kesehatan menetapkan strategi operasional pembangunan kesehatan melalui Program Indonesia Sehat Dengan Pendekatan Keluarga (Kemenkes RI,2016).

Keluarga adalah suatu lembaga yang merupakan satuan (unit) terkecil dari masyarakat, terdiri atas ayah, ibu, dan anak. Keluarga yang seperti ini disebut rumah tangga atau keluarga inti (keluarga batih). Sedangkan keluarga yang anggotanya mencakup juga kakek dan atau nenek atau individu lain yang memiliki hubungan darah, bahkan juga tidak memiliki hubungan darah (misalnya pembantu rumah tangga), disebut keluarga luas (extended family). Oleh karena merupakan unit terkecil dari masyarakat, maka derajat kesehatan rumah tangga atau keluarga menentukan derajat kesehatan masyarakatnya.(Fauziah AN,2018)

Program Indonesia Sehat dengan Pendekatan Keluarga merupakan salah satu upaya yang dilakukan Puskesmas untuk meningkatkan jangkauan sasaran dan meningkatkan akses masyarakat pada pelayanan keluarga (Kemenkes RI, 2017).

STIKES Mamba'ul Ulum Surakarta merupakan salah satu perguruan tinggi kesehatan di Kota Surakarta yang dalam lingkup tridharma perguruan tinggi mempunyai daerah binaan di Kalurahan Mojosongo Surakarta. Upaya yang rutin setiap tahun sekali adalah pelaksanaan praktek Pembangunan Kesehatan Masyarakat Desa yang pada tahun 2018 ini dilakukan di RW 12 Kalurahan Mojosongo dengan diawali kegiatan pendataan kesehatan ibu dan anak dengan pendekatan keluarga, pengkajian serta analisa data, pelaksanaan perencanaan kegiatan dalam upaya melakukan intervensi masalah kesehatan ibu dan anaka yang ditemui serta melakukan evaluasi .

Upaya ini tentunya sangat mendukung kegiatan puskesmas setempat yaitu Puskesmas Sibela Mojosongo Surakarta dalam upaya mewujudkan Program Indonesia Sehat dengan Pendekatan Keluarga ( PIS PK).

\section{METODE PENELITIAN}

Penelitian ini adalah penelitian deskriptif dengan pendekatan cross sectional. Populasi dalam penelitian ini adalah semua keluarga yang tinggal di RW 12 Kalurahan Mojosongo Surakarta, sedangkan tehnik pengambilan sampel menggunakan purposive sampling yaitu keluarga yang memiliki bayi,balita maupun ibu hamil yang mendapatkan rekomendasi dari kader posyandu sejumlah

Gambaran Kesehatan Ibu Dan Anak Dengan Pendekatan Keluarga Di Rw 12 Kalurahan Mojosongo Surakarta (Ani Nur Fauziah, Siti Maesaroh) 
204 keluarga. Alat pengumpulan data yang digunakan adalah kuesioner, sedangkan analisa data menggunakan distribusi frekuensi.

\section{HASIL PENELITIAN DAN PEMBAHASAN}

Berdasarkan hasil kegiatan yang dilakukan selama 3 minggu yang meliputi dari peengkajian data sampai dengan evaluasi pelaksanaan kegiatan di peroleh hasil sebagai berikut :

\section{Data Jumlah Kepala Keluarga}

Tabel 1 Data Jumlah Kepala Keluarga Yang Memiliki Bayi dan Balita maupun ibu hamil di RW 12 Kalurahan Mojosongo Surakarta

\begin{tabular}{cccc}
\hline No & Keterangan & $\begin{array}{c}\text { Jumlah Kepala Keluarga } \\
\text { Prosentase } \\
(\%)\end{array}$ \\
\hline 1 & RT 1 & 23 & 11.2 \\
2 & RT 2 & 20 & 9.8 \\
3 & RT 3 & 20 & 9.8 \\
4 & RT 4 & 20 & 9.8 \\
5 & RT 5 & 40 & 19.6 \\
6 & RT 6 & 39 & 19.2 \\
7 & RT 7 & 20 & 9.8 \\
8 & RT 8 & 22 & 10.8 \\
\hline
\end{tabular}

Berdasarkan tabel 1 diatas dapat diketahui bahwa jumlah bayi dan balita terbanyak ada di RT 05 yaitu 40 orang $(19,6 \%)$.

\section{Data Kesehatan Bayi dan Balita}

Tabel 2 Data Jumlah Bayi dan Balita Yang Memiliki KMS di RW 12 Kalurahan Mojosongo Surakarta

\begin{tabular}{ccccc}
\hline No & Keterangan & $\begin{array}{c}\text { Jumlah Bayi } \\
\text { dan Balita }\end{array}$ & $\begin{array}{c}\text { Jumlah Bayi } \\
\text { dan Balita } \\
\text { Yang memiliki } \\
\text { KMS }\end{array}$ & $\begin{array}{c}\text { Prosentase } \\
(\%)\end{array}$ \\
\hline 1 & RT 1 & 22 & 22 & 100 \\
2 & RT 2 & 17 & 17 & 100 \\
3 & RT 3 & 12 & 12 & 100 \\
4 & RT 4 & 23 & 23 & 100 \\
5 & RT 5 & 32 & 30 & 94 \\
6 & RT 6 & 36 & 36 & 100 \\
7 & RT 7 & 15 & 15 & 90 \\
8 & RT 8 & 21 & 19 & 98 \\
\hline
\end{tabular}

Berdasarkan tabel 2 di atas ada 4 bayi balita (2\%) yang tidak memiliki KMS ( Kartu Menuju Sehat). Kartu Menuju Sehat merupakan kartu yang memuat kurva pertumbuhan normal anak berdasarkan indeks antropometri berat badan

Gambaran Kesehatan Ibu Dan Anak Dengan Pendekatan Keluarga Di Rw 12 Kalurahan Mojosongo Surakarta (Ani Nur Fauziah, Siti Maesaroh) 
menurut umur. Melalui KMS ini gangguan pertumbuhan atau resiko kelebihan gizi dapat diketahui sejak dini sehingga dapat dilakukan tindakan pencegahan secara lebih cepat dan tepat sebelum masalahnya lebih berat (Kemenkes, 2009). Berdasarkan hasil pendataan tersebut upaya yang dilakukan adalah melakukan pendekatan keluarga serta memberikan penyuluhan tentang pentingnya memiliki KMS bagi bayi balita serta berkoordinasi dengan puskesmas Sibela untuk menyediakan KMS bagi 4 balita tersebut.

Tabel 3 Data Jumlah Bayi dan Balita yang melakukan penimbangan rutin di RW 12 Kalurahan Mojosongo Surakarta

\begin{tabular}{ccccc}
\hline No & Keterangan & $\begin{array}{c}\text { Jumlah Bayi } \\
\text { dan Balita }\end{array}$ & $\begin{array}{c}\text { Jumlah Bayi } \\
\text { dan Balita } \\
\text { Yang } \\
\text { melakukan } \\
\text { timbang rutin }\end{array}$ & $\begin{array}{c}\text { Prosentase } \\
(\%)\end{array}$ \\
\hline 1 & RT 1 & 22 & 22 & 100 \\
2 & RT 2 & 17 & 17 & 100 \\
3 & RT 3 & 12 & 11 & 91.7 \\
4 & RT 4 & 23 & 23 & 100 \\
5 & RT 5 & 32 & 31 & 96.9 \\
6 & RT 6 & 36 & 31 & 86.1 \\
7 & RT 7 & 15 & 14 & 100 \\
8 & RT 8 & 21 & 21 & 96 \\
\hline
\end{tabular}

Tabel 3 menjelaskan ada 8 bayi balita (4 \%) yang tidak melakukan penimbangan rutin diposyandu RW 12 Kalurahan Mojosongo Surakarta. Posyandu yang ada di RW 12 ada 3 posyandu yaitu : Posyandu 12 A adalah posyandu yang memberikan pelayanan pada bayi dan balita di RT 1 dan RT 2, Posyandu $12 \mathrm{~B}$ adalah posyandu yang memberikan pelayanan pada bayi dan balita di RT 3, RT 7 dan RT 8 dan Posyandu 12 C merupakan posyandu yang memberikan pelayanan pada bayi dan balita di RT 4, RT 5 dan RT 6

Pemanfaatan posyandu Pemanfaatan posyandu sangat penting untuk memantau perkembangan dan kondisi kesehatan balita. Hal tersebut mempunyai pengaruh yang sangat besar terhadap status gizi balita sehingga kunjungan ke posyandu harus dilakukan secara rutin dan teratur. Memanfaatkan posyandu bukan hanya datang ke posyandu secara rutin saja akan tetapi juga mendapatkan berbagai pelayanan kesehatan yang tersedia di posyandu baik bagi ibu atau balita (Octaviani,2008 dalam Fitria ,2015).

Adapun upaya yang dilakukan terkait dengan adanya 8 bayi balita yang tidak melakukan penimbangan rutin adalah dengan memberikan penyuluhan kepada $8 \mathrm{ibu}$ yang tidak melakukan penimbangan rutin tentang pentingnya melakukan penimbangan rutin ke posyandu adalah untuk memantau status gizi bayi balitanya dan dilakukan pemantauan kehadirannya pada pelaksanaan penimbangan berikutnya.

Gambaran Kesehatan Ibu Dan Anak Dengan Pendekatan Keluarga Di Rw 12 Kalurahan Mojosongo Surakarta (Ani Nur Fauziah, Siti Maesaroh) 
Tabel 4 Data Status Gizi Bayi dan Balita di RW`12 Kalurahan Mojosongo Surakarta

\begin{tabular}{|c|c|c|c|c|c|c|c|c|c|c|}
\hline \multirow[t]{2}{*}{ No } & \multirow{2}{*}{$\begin{array}{l}\text { Ketera } \\
\text { ngan }\end{array}$} & \multicolumn{8}{|c|}{ Status Gizi Bayi dan Balita } & \multirow{2}{*}{$\begin{array}{l}\text { Jum } \\
\text { Lah }\end{array}$} \\
\hline & & $\begin{array}{c}\text { Sangat } \\
\text { Kurus }\end{array}$ & $\%$ & $\begin{array}{l}\mathrm{Ku} \\
\text { rus }\end{array}$ & $\%$ & $\begin{array}{l}\text { Nor } \\
\text { mal }\end{array}$ & $\%$ & $\begin{array}{c}\mathrm{Ge} \\
\mathrm{muk}\end{array}$ & $\%$ & \\
\hline 1 & RT 1 & 1 & 4.5 & 0 & 0 & 18 & 81.8 & 3 & 13.7 & 22 \\
\hline 2 & RT 2 & 0 & 0 & 0 & 0 & 17 & 100 & 0 & 0 & 17 \\
\hline 3 & RT 3 & 0 & 0 & 0 & 0 & 10 & 83.3 & 2 & 16.7 & 12 \\
\hline 4 & RT 4 & 1 & 4.3 & 1 & 4.3 & 21 & 91.4 & 0 & 0 & 23 \\
\hline 5 & RT 5 & 0 & 0 & 4 & 12.5 & 28 & 87.5 & 0 & 0 & 32 \\
\hline 6 & RT 6 & 0 & 0 & 0 & 0 & 36 & 100 & 0 & 0 & 36 \\
\hline 7 & RT 7 & 0 & 0 & 1 & 6.7 & 13 & 86.6 & 1 & 6.7 & 15 \\
\hline 8 & RT 8 & 0 & 0 & 3 & 14.3 & 17 & 81 & 1 & 4.7 & 21 \\
\hline & Jumlah & 2 & 1.1 & 9 & 5.1 & 160 & 89.9 & 7 & 3.9 & 178 \\
\hline
\end{tabular}

Data status gizi bayi balita di RW 12 kalurahan Mojosongo Surakarta Terdapat 2 anak dengan status gizi sangat kurus $(1,1 \%), 9$ anak kurus $(5,1 \%)$ dan 7 anak gemuk $(3,9 \%)$. Adapun upaya yang dilakukan untuk mengatasi masalah ini adalah:

a. Memberikan penyuluhan kepada ibu melalui kunjungan rumah tentang kebutuhan gizi bagi bayi dan balita termasuk cara pengolahan dan penyajian makanan yang benar dan sehat.

b. Melakukan koordinasi dengan Puskesmas Sibela dalam upaya Pemberian Makanan Tambahan ( PMT) bagi 11 kasus bayi balita yang status gizinya sangat kurus dan kurus.

c. Mengikuti kegiatan posyandu di RW 12 Kalurahan Mojosongo Surakarta untuk memantau status gizi bayi balita.

Pengetahuan ibu tentang gizi merupakan salah satu faktor yang dapat mempengaruhi konsumsi pangan. Ibu yang memiliki pengetahuan tentang gizi yang cukup akan bisa memperhitungkan kebutuhan gizi anak balitanya sehingga pertumbuhan dan perkembangannya dapat secara optimal. Selain itu pengetahuan ibu akan mempengaruhi jenis dan jumlah makanan yang dikonsumsi anaknya. (Ulfa O,2008 dalam Yogiswara AD,2011).

\section{Data Kesehatan Ibu Hamil}

Tabel 5 Data Status Gizi Ibu Hamil di RW 12 Kalurahan Mojosongo Surakarta

\begin{tabular}{|c|c|c|c|c|c|c|c|c|c|c|}
\hline \multirow[t]{2}{*}{ No } & \multirow[t]{2}{*}{ Keterangan } & \multicolumn{8}{|c|}{ Status Gizi Ibu Hamil } & \multirow{2}{*}{$\begin{array}{c}\text { Jum } \\
\text { Lah } \\
\text { bu } \\
\text { mil }\end{array}$} \\
\hline & & $\begin{array}{c}\text { Tidak } \\
\text { Ane } \\
\text { mia }\end{array}$ & $\%$ & $\begin{array}{c}\text { Ti } \\
\text { dak } \\
\text { KEK } \\
\end{array}$ & $\%$ & $\begin{array}{c}\text { Ti } \\
\text { Dak } \\
\text { Resti }\end{array}$ & $\%$ & $\begin{array}{c}\mathrm{HbS} \\
\mathrm{Ag}(- \\
)\end{array}$ & $\%$ & \\
\hline 1 & RT 1 & 3 & 75 & 3 & 75 & 4 & 100 & 4 & 100 & 4 \\
\hline 2 & RT 2 & 3 & 100 & 3 & 100 & 2 & 67 & 3 & 100 & 3 \\
\hline 3 & RT 3 & 3 & 100 & 3 & 100 & 3 & 100 & 2 & 67 & 3 \\
\hline 4 & RT 4 & 0 & 0 & 1 & 100 & 1 & 100 & 1 & 100 & 1 \\
\hline 5 & RT 5 & 3 & 100 & 2 & 67 & 2 & 67 & 3 & 100 & 3 \\
\hline 6 & RT 6 & 2 & 100 & 2 & 100 & 2 & 100 & 2 & 100 & 2 \\
\hline 7 & RT 7 & 2 & 100 & 1 & 50 & 2 & 100 & 2 & 100 & 2 \\
\hline 8 & RT 8 & 2 & 100 & 2 & 100 & 1 & 50 & 2 & 100 & 2 \\
\hline & Jumlah & 18 & 90 & 17 & 85 & 17 & 85 & 19 & 95 & 20 \\
\hline
\end{tabular}

Gambaran Kesehatan Ibu Dan Anak Dengan Pendekatan Keluarga Di Rw 12 Kalurahan Mojosongo Surakarta (Ani Nur Fauziah, Siti Maesaroh) 
Dari Tabel diatas diketahui ada 2 ibu hamil (10\%) anemia yaitu di RT 1 dan RT 4 serta ada 3 ibu hamil ( 15\%) mengalami Kurang Energi Kronis ( KEK) yaitu di RT 1,RT 5 dan RT 7. Upaya yang dilakukan adalah dengan memberikan penyuluhan tentang anemia dalam kehamilan serta upaya pencegahannya yaitu dengan mengkonsumsi tablet $\mathrm{Fe}$ secara rutin serta memberikan penyuluhan gizi bagi ibu hamil.

Untuk ibu hamil yang memiliki resiko tinggi ada 3 (15\%) yaitu dengan kondisi 1 ibu hamil di RT 2 karena jarak kehamilan yang terlalu jauh, 1 ibu hamil di RT 5 mengalami urine reduksi positif serta 1 ibu hamil (5\%) di RT 8 karena jarak kehamilan yang terlalu dekat serta ada 1 ibu hamil (5\%) di RT 3 yang HbsAG positif yang berarti bahwa ibu tersebut menderita penyakit Hepatitis B yang bisa berdampak pada penularan ke janin yang dikandungnya. Dalam mengatasi masalah ini adalah melakukan koordinasi dengan puskesmas Sibela dalam upaya pemantauan status kesehatan ibu hamil disamping itu juga diberikan penyuluhan kesehatan terkait dengan permasalahannya.

Tabel 6 Data Ibu Hamil yang Memiliki Buku KIA di RW 12 Kalurahan Mojosongo Surakarta

\begin{tabular}{ccccc}
\hline No & Keterangan & $\begin{array}{c}\text { Jumlah Ibu } \\
\text { Hamil }\end{array}$ & $\begin{array}{c}\text { Jumlah Ibu Hamil } \\
\text { yang memiliki } \\
\text { Buku KIA }\end{array}$ & $\begin{array}{c}\text { Prosentase } \\
(\%)\end{array}$ \\
\hline 1 & RT 1 & 4 & 4 & 100 \\
2 & RT 2 & 3 & 3 & 100 \\
3 & RT 3 & 3 & 3 & 100 \\
4 & RT 4 & 1 & 1 & 100 \\
5 & RT 5 & 3 & 3 & 100 \\
6 & RT 6 & 2 & 0 & 0 \\
7 & RT 7 & 2 & 2 & 100 \\
8 & RT 8 & 2 & 1 & 50 \\
\hline & Jumlah & 20 & 17 & 85 \\
\hline
\end{tabular}

Berdasarkan Tabel 6 diatas ada 3 ibu hamil (15\%) yang tidak memiliki Buku Kesehatan Ibu dan Anak ( KIA). Buku KIA merupakan alat komunikasi dan media informasi yang penting bagi tenaga kesehatan, ibu hamil, keluarga dan masyarakat yang berfungsi sebagai alat untuk mengetahui status kesehatan ibu hamil, dokumentasi, deteksi dini adanya resiko, konseling serta untuk memantau tumbuh kembang balita (Ainiyah NH,2017).

Peningkatan implementasi buku Kesehatan Ibu dan Anak (KIA) didukung oleh pemerintah pusat sebagai salah satu program untuk meningkatkan kesehatan Ibu dan Anak, menuntun petugas kesehatan memberikan pelayanan kesehatan ibu dan anak sesuai standart, melakukan dokumentasi secara baik dan benar, serta merupakan satu satunya bukti yang dipegang ibu sebagai dokumentasi status kesehatanya selama hamil, bersalin, nifas, imunisasi dan tumbuh kembang balita, sehingga mempermudah ibu dan keluarga serta petugas kesehatan mengetahui riwayat kesehatan ibu dan anak (Kemenkes, 2015).

Gambaran Kesehatan Ibu Dan Anak Dengan Pendekatan Keluarga Di Rw 12 Kalurahan Mojosongo Surakarta (Ani Nur Fauziah, Siti Maesaroh) 
Tabel 7 Data Ibu Hamil yang terpasang stiker P4K di RW 12 Kalurahan Mojosongo Surakarta

\begin{tabular}{ccccc}
\hline No & Keterangan & $\begin{array}{c}\text { Jumlah Ibu } \\
\text { Hamil }\end{array}$ & $\begin{array}{c}\text { Jumlah ibu Hamil yang } \\
\text { terpasang stiker P4K }\end{array}$ & $\begin{array}{c}\text { Prosentase } \\
(\%)\end{array}$ \\
\hline 1 & RT 1 & 4 & 1 & 25 \\
2 & RT 2 & 3 & 3 & 100 \\
3 & RT 3 & 3 & 3 & 100 \\
4 & RT 4 & 1 & 1 & 100 \\
5 & RT 5 & 3 & 3 & 100 \\
6 & RT 6 & 2 & 0 & 0 \\
7 & RT 7 & 2 & 2 & 100 \\
8 & RT 8 & 2 & 2 & 100 \\
\hline & Jumlah & 20 & 15 & 75 \\
\hline
\end{tabular}

Dari total $20 \mathrm{ibu}$ hamil ada $5 \mathrm{ibu}$ hamil (25\%) yang rumahnya belum terpasang stiker P4K ( Perencanaan Persalinan dan Pencegahan Komplikasi). P4K dengan stikerisasi oleh bidan adalah program perencanaan persalinan dan pencegahan komplikasi yang merupakan kegiatan yang difasilitasi oleh bidan dalam rangka peningkatan peran aktif suami, keluarga dan masyarakat dalam merencanakan persalinan yang aman dan persiapan menghadapi komplikasi bagi ibu hamil termasuk perencanaan penggunaan KB pasca persalinan dengan menggunakan stiker sebagai media notifikasi sasaran dalam rangka peningkatan cakupan dan mutu pelayanan kesehatan ibu dan bayi baru lahir. ( Depkes, 2009).

Pemasangan stiker pada masing - masing rumah ibu hamil merupakan program $\mathrm{P} 4 \mathrm{~K}$ yang dilaksanakan oleh bidan akan tetapi ada beberapa kendala yang dihadapi adalah kurangnya pemahaman masyarakat, keluarga dan ibu tentang tujuan dan manfaat $\mathrm{P} 4 \mathrm{~K}$, kurangnya informasi dari petugas kesehatan (Hidayati T dan Safitri MU, 2018).

Adapun upaya yang dilakukan adalah berkoordinasi dengan puskesmas Sibela dalam pengadaan dan penempelan stiker P4K di rumah 5 orang ibu hamil yang belum ada serta penyuluhan kepada ibu hamil tersebut tentang P4K.

Tabel 8 Data Status Imunisasi TT Ibu Hamil di RW 12 Kalurahan Mojosongo Surakarta

\begin{tabular}{ccccc}
\hline No & Keterangan & $\begin{array}{c}\text { Jumlah Ibu } \\
\text { Hamil }\end{array}$ & $\begin{array}{c}\text { Jumlah Ibu Hamil } \\
\text { yang imunisasi TT }\end{array}$ & $\begin{array}{c}\text { Prosentase } \\
(\%)\end{array}$ \\
\hline 1 & RT 1 & 4 & 4 & 100 \\
2 & RT 2 & 3 & 3 & 100 \\
3 & RT 3 & 3 & 2 & 67 \\
4 & RT 4 & 1 & 0 & 0 \\
5 & RT 5 & 3 & 3 & 100 \\
6 & RT 6 & 2 & 0 & 0 \\
7 & RT 7 & 2 & 0 & 0 \\
8 & RT 8 & 2 & 2 & 100 \\
\hline & Jumlah & 20 & 14 & 70 \\
\hline
\end{tabular}

Ada 6 ibu hamil (30\%) yang tidak melakukan imunisasi Tetanus Toksoid TT). Imuniasi TT ini merupakan salah satu program Millenium Development Goals (MDGs) yang bertujuan meningkatkan kesehatan ibu dan bayi dengan

Gambaran Kesehatan Ibu Dan Anak Dengan Pendekatan Keluarga Di Rw 12 Kalurahan Mojosongo Surakarta (Ani Nur Fauziah, Siti Maesaroh) 
eliminasi tetanus maternal dan tetanus neonatarum. Beberapa cara diantaranya melakukan imunisasi TT dengan pencapaian tinggi dan merata, melakukan persalinan bersih dan aman ( WHO, 2017).

Peraturan Menteri Kesehatan Nomor 42 tahun 2013 Tentang Penyelenggaraan Imunisasi mengamanatkan bahwa wanita usia subur dan ibu hamil merupakan salah satu sasaran imunisasi lanjutan yaitu imunisasi TT yang diberikan sebanyak 5 dosis dengan interval waktu tertentu dimulai sebelum dan saat hamil yang berguna bagi kekebalan seumur hidup. (Dinkes Kota Batu, 2017)

Tabel 9 Data Ibu Hamil yang Mengkonsumsi Tablet Fe di RW 12 Kalurahan

\begin{tabular}{ccccc}
\multicolumn{4}{l}{ Mojosongo Surakarta } \\
\hline No & Keterangan & $\begin{array}{c}\text { Jumlah } \\
\text { Ibu Hamil }\end{array}$ & $\begin{array}{c}\text { Jumlah Ibu Hamil yang } \\
\text { mengkonsumsi tablet Fe }\end{array}$ & $\begin{array}{c}\text { Prosentase } \\
(\%)\end{array}$ \\
\hline 1 & RT 1 & 4 & 4 & 100 \\
2 & RT 2 & 3 & 3 & 100 \\
3 & RT 3 & 3 & 3 & 100 \\
4 & RT 4 & 1 & 1 & 100 \\
5 & RT 5 & 3 & 3 & 100 \\
6 & RT 6 & 2 & 0 & 50 \\
7 & RT 7 & 2 & 0 & 0 \\
8 & RT 8 & 2 & 15 & 0 \\
\hline \multicolumn{7}{r}{} & Jumlah & 20 & & 75 \\
\hline
\end{tabular}

Ada 5 ibu hamil (25\%) yang tidak mengkonsumsi tablet Fe yaitu di RT 6,7 dan 8. Kebutuhan zat besi selama kehamilan rata - rata $800 \mathrm{mg}-1040 \mathrm{mg}$. Program pemerintah saat ini, setiap ibu hamil mendapatkan tablet besi 90 tablet selama kehamilannya. Tablet besi yang diberikan mengandung FeSO4 $320 \mathrm{mg}$ (zat besi $60 \mathrm{mg}$ ) dan asam folat 0,25 mg. Program tersebut bertujuan mencegah dan menangani masalah anemia pada ibu hamil. Kebutuhan Fe selama hamil sebesar 800-1040 mg, untuk pertumbuhan janin, plasenta, meningkatkan masa hemoglobin ibu, sekresi dan hilang saat melahirkan ( Susiloningtyas I, 2012).

Berdasarkan informasi yang digali dari pengkajian data keluarga, ibu yang tidak mengkonsumsi tablet Fe tersebut karena merasa mual setelah minum tablet fe tersebut. Ketidakpatuhan untuk mengkonsumsi tablet Fe ini dapat terjadi karena ibu hamil merasa mual akibat rasa dan bau tablet. Selain itu, tablet besi yang dikonsumsi setiap hari menimbulkan rasa bosan, sehingga ibu hamil lupa dan malas untuk mengonsumsinya. Motivasi merupakan faktor paling dominan berhubungan dengan kepatuhan mengonsumsi tablet besi folat. Makin baik motivasi, makin patuh ibu hamil mengonsumsi besi folat. (Budiarni W, 2012).

Tindakan yang dilakukan untuk mengatasi hal ini adalah melakukan penyuluhan kesehatan tentang Tablet Fe dalam upaya mencegah anemia dalam kehamilan kepada 5 ibu hamil tersebut melalui kunjungan ulang serta memantau tablet Fe untuk selalu dikonsumsi. Anemia dalam kehamilan dapat menyebabkan dampak yang membahayakan bagi ibu dan janin. Anemia pada ibu hamil dapat meningkatkan resiko terjadinya perdarahan post partum. Anemia yang terjadi

Gambaran Kesehatan Ibu Dan Anak Dengan Pendekatan Keluarga Di Rw 12 Kalurahan Mojosongo Surakarta (Ani Nur Fauziah, Siti Maesaroh) 
sejak awal kehamilan dapat menyebabkan resiko terjadinya prematur (Mochtar, 2008).

Upaya diatas mendapatkan respon positif dari masyarakat RW 12 Kalurahan Mojosongo Surakarta dan mendapatkan dukungan dari Kalurahan Mojosongo Surakarta serta Puskesmas Sibela dalam upaya mewujudkan kesehatan masyarakat di RW 12 kalurahan Mojosongo Surakarta.

\section{SIMPULAN DAN SARAN}

\section{Simpulan}

Pendekatan Keluarga dalam upaya memperoleh data kesehatan ibu dan anak di RW 12 Kalurahan Mojosongo Surakarta diperoleh hasil sebagai berikut data kesehatan bayi balita adalah ada 8 bayi balita (4\%) yang tidak melakukan penimbangan rutin di posyandu, sedangkan untuk kesehatan ibu hamil ada $6 \mathrm{ibu}$ hamil $(30 \%)$ yang tidak melakukan imunisasi tetanus toksoid.

\section{Saran}

Adanya peningkatan kesadaran masyarakat RW 12 Kalurahan Mojosongo setelah dilakukan kegiatan pendataan kesehatan ibu dan anak dengan pendekatan keluarga serta peningkatan pengetahuan tentang kesehatan ibu dan anak melalui kegiatan posyandu balita maupun kelompok pendukung ibu. Disamping itu dilakukan kegiatan pemantauan tindak lanjut pelaksanaan intervensi kesehatan yang telah dilaksanakan oleh Puskesmas Sibela dalam upaya perubahan perilaku kesehatan ibu dan anak secara konsisten di RW 12 kalurahan Mojosongo Surakarta.

\section{DAFTAR PUSTAKA}

Ainiyah, NH.2017. Hubungan Pemanfaatan Buku Kesehatan Ibu dan Anak (KIA) dengan Tingkat Pengetahuan dan Perilaku Kesehatan Ibu Hamil Trimester III di Puskesmas Jagir Surabaya. Naskah Publikasi. Prodi Magister Kebidanan Universitas Aisyiyah.Yogyakarta

Budiarni W, Subagio HW .2012. Hubungan pengetahuan, sikap dan motivasi dengan kepatuhan konsumsi tablet besi folat pada ibu hamil. Journal of Nutrition College.1.96-106.

Dinkes Kota Batu, 2017. Profil Kesehatan Kota Batu tahun 2016. Dinas Kesehatan Kota Batu.Batu http://www.depkes.go.id/resources/download/profil/PROFIL_KAB_KOTA 2016/3579_Jatim_Kota_Batu_2016.pdf

Fauziah, A.N., 2018. Keluarga Sehat Berdasarkan Pendekatan Keluarga Di RW 03 Kalurahan Mokosongo Surakarta Tahun 2016. Jurnal Kebidanan Indonesia: Journal of Indonesia Midwifery, 8(1). 101-110 https://jurnal.stikesmus.ac.id/index.php/JKebIn/article/view/165

Gambaran Kesehatan Ibu Dan Anak Dengan Pendekatan Keluarga Di Rw 12 Kalurahan Mojosongo Surakarta (Ani Nur Fauziah, Siti Maesaroh) 
Fitria, Azmi N. 2015.Hubungan Pemanfaatan Posyandu dengan Status Gizi Balita di Kecamatan Kota Jantho. Idea Noursing Journal.VI(1) :1-6

Hidayati T, Safitri MU.2018. Hubungan Pengetahuan Tentang P4K ( Perencanaan Persalinan dan Pencegahan Komplikasi) dengan Pemilihan Penolong Persalinan. Jurnal Keperawatan.11(2): 1-6

Kementrian Kesehatan RI.2009.Pedoman Penggunaan Kartu Menuju Sehat (KMS) Balita. Jakarta

Kementerian Kesehatan R I. 2015. Buku Kesehatan Ibu dan Anak. JICA: Jakarta

Kemenkes RI. 2016. Pedoman Umum Program Indonesia Sehat dengan Pendekatan Keluarga. Jakarta: Kemenkes RI

Kementrian Kesehatan RI.2017. Pedoman Monitoring dan Evaluasi Pelaksanaan Program Indonesia Sehat dengan Pendekatan Keluarga. Jakarta

Mochtar, R. 2008 . Sinopsis Obstetri.Jakarta. EGC.

Susiloningtyas, I., 2012. Pemberian zat besi (Fe) dalam Kehamilan. Majalah Ilmiah Sultan Agung. 50(128). pp.73-99.

http://jurnal.unissula.ac.id/index.php/majalahilmiahsultanagung/article/view/74

World Health Organization. 2017. Maternal and Neonatal Tetanus Elimination (MNTE). https://www.who.int/immunization/diseases/MNTE_initiative/en/

Yogiswara, AD.2011. Hubungan Antara Tingkat Partisipasi Ibu di Posyandu dengan Status Gizi Balita. Skripsi. Program Pendidikan Sarjana Kedokteran Universitas Diponegoro.Semarang 